\title{
One technology, two pathways? Strategic Niche Management and the diverging diffusion of concentrated solar power in South Africa and the United States
}

\author{
Pegah Mirzania $^{a}$ Nazmiye Balta-Ozkana Lochner Marais ${ }^{b}$ \\ School of Water, Energy and Environment, Cranfield University, Cranfield, UK \\ b \\ Centre for Development Support, University of the Free State, Bloemfontein 9301, South Africa
}

\begin{abstract}
:
The transition towards a low carbon energy system requires significant deployment of renewable energy technologies. Concentrated Solar Power (CSP) plants could contribute to a low carbon energy system, with an estimated potential global capacity of over $600 \mathrm{GW}$ by 2030. Despite this potential, however, the CSP industry lags behind other renewable technologies, with only about $4 \%$ of its estimated global potential expected to be realised in the next decade. This paper investigates the reasons for this by comparing CSP in the US, where $60 \%$ of worldwide capacity is currently located, with South Africa, where its development has been slow despite an abundance of natural solar-energy resources. Using strategic niche management analysis, we identify replicable success factors that could accelerate the uptake of CSP projects in developing countries. The results reveal that the main reason for the successful diffusion and adoption of CSP in the US is consistent policy support, which has made it possible to bridge the gap between research and development and emerge in the market. By contrast, the development of CSP in South Africa has been hindered by several technical and economic problems, including a lack of technological expertise, resources and funding.
\end{abstract}

Keywords: Concentrated solar power (CSP); Niche formation; Strategic niche management; Solar energy; Developing economy; Diffusion 


\section{Introduction}

Despite consistent growth in the renewable energy market, current carbon emission targets are unlikely to be achieved globally. According to the IEA [1], to achieve the goal of limiting global warming to $2^{\circ} \mathrm{C}$, low-carbon energy must replace approximately $850 \mathrm{GW}$ of electricity currently generated by coal-fired power stations.

In 2015, developing countries accounted for $63 \%$ of global greenhouse emissions [2] and this percentage is increasing $[3,4]$. South Africa is one of the biggest sources, being responsible for $40 \%$ of emissions in sub-Saharan Africa [4-6]. The country relies on coal-fired generation for around $68 \%$ of its total primary energy supply [7].

One technology that could contribute significantly to a low carbon future is Concentrated Solar Power (CSP). CSP plants can store thermal energy, which means they can supply electricity after sunset or when the weather is cloudy, making solar generation more reliable [8]. Utilityscale CSP plants were first installed in the US, in California, between 1984 and 1991, where they have proven to be a reliable contributor to the Californian grid [9].

CSP applications have grown more slowly than other types of renewable energy. One reason for this is that CSP projects require sites with high insolation, ideally direct sunshine of over $1900 \mathrm{kWh} / \mathrm{m}^{2}$ per year. This requirement restricts CSP's potential deployment in Mediterranean regions like Spain, southern Italy, southern France, Greece, Cyprus and Malta $[10,11]$. However, opportunities abound for the development of CSP in sunnier regions, such as in the Sun Belt region of the southern US, and in many developing countries in the Middle East, Central and South America, Africa and South Asia. In some of these locations, annual solar irradiation can be as high as $2500 \mathrm{kWh} / \mathrm{m}^{2}$ [12,13]. In some parts of South Africa the solar irradiation is even higher than this. Upington in the Northern Cape Province, for example, 
has an annual direct normal irradiance (DNI) of $2800 \mathrm{kWh} / \mathrm{m}^{2}$ [14], one of the highest in the world. If South Africa fully exploited its solar resource, it could accommodate over $500 \mathrm{GW}$ of CSP projects [15]. But despite this remarkable potential, the entire country currently has only $500 \mathrm{MW}$ of operational CSP plant [16].

Worldwide, most CSP projects are in the US (60\%, mainly in California) and Spain (27\%) [8]. The most commonly cited reason for other countries being so slow to take advantage of CSP is the high capital cost involved $[9,13,17]$. Compared to other renewable technologies, constructing a CSP plant requires considerable investment, often a problem for a developing country like South Africa, where finance costs are high because of political and economic risk factors $[10,12,17]$. Schinko and Komendantova [18] note that the weighted capital cost of deploying a CSP project in an African country is more than double that in Europe. Trieb et al. [9] observe that importing low-cost power plants from developed countries and using subsidies from international institutions often does not sufficiently offset these costs and the associated risks to make a CSP project financially feasible for a developing country. They advise that successful diffusion of CSP requires a financial strategy that can compensate for the political and economic risks of the particular region.

Other obstacles besides finance may limit the uptake of this technology [17]. Mahia et al. [19] say that policy-related barriers and a lack of government support in developing countries, particularly in the Middle East and North Africa, are more critical than economic constraints. Opazo [20] says problems like a lack of technological expertise, insufficient resources, and limited involvement by industrial actors hinder the development of innovative technologies in developing countries, and Elmustapha et al.[21] say poor investment in research and development is a common hindrance. 
Most published analysis of the slow development of CSP in developing countries has investigated these economic, political and technical barriers to uptake, but a more rigorous and systematic approach is now needed. This paper uses a strategic niche management (SNM) approach to investigate the diffusion and development of CSP projects. The SNM framework was developed by Kemp et al. [22] to analyse the way that technological change and its social acceptance evolve together. SNM, as a research method, can help to investigate how a new technology has been successfully introduced in the past, and to determine the required conditions for successful diffusion and development of radical innovations in the future. A few researchers have already applied it to the emergence of alternative energy technology in developing countries [21,23]. We used SNM framework to investigate the faltering progress of CSP projects in South Africa as compared with their successful implementation in California. We wanted to know whether SNM helps to explain the marked difference between CSP development in South Africa and in the US, and whether any lessons from the successful introduction of CSP in the US could be transferred to a country like South Africa.

To find the answers, we first identified institutional, social and techno-economic obstacles that have restricted the development of CSP projects and used the SNM framework to evaluate and compare the development of CSP niches in the US and South Africa. We then considered what lessons might be transferrable, to accelerate the uptake of CSP in South Africa and other developing countries.

Section 2 reviews the literature on the CSP industry and identifies the barriers to its development, Section 3 explains the SNM framework, Section 4 describes our data collection methods, Section 5 reports our results, and Section 6 concludes with policy recommendations. 


\section{Overview of the development of CSP niches}

Figure 1 illustrates the four CSP technologies that are currently in use around the world: Linear Fresnel Reflector (LFR), Solar power tower, Stirling parabolic dish, and Parabolic Trough Collector (PTC), All of these four CSP typologies, regardless of the type of their technology, contain three main components: a solar field, a power block and storage [8].

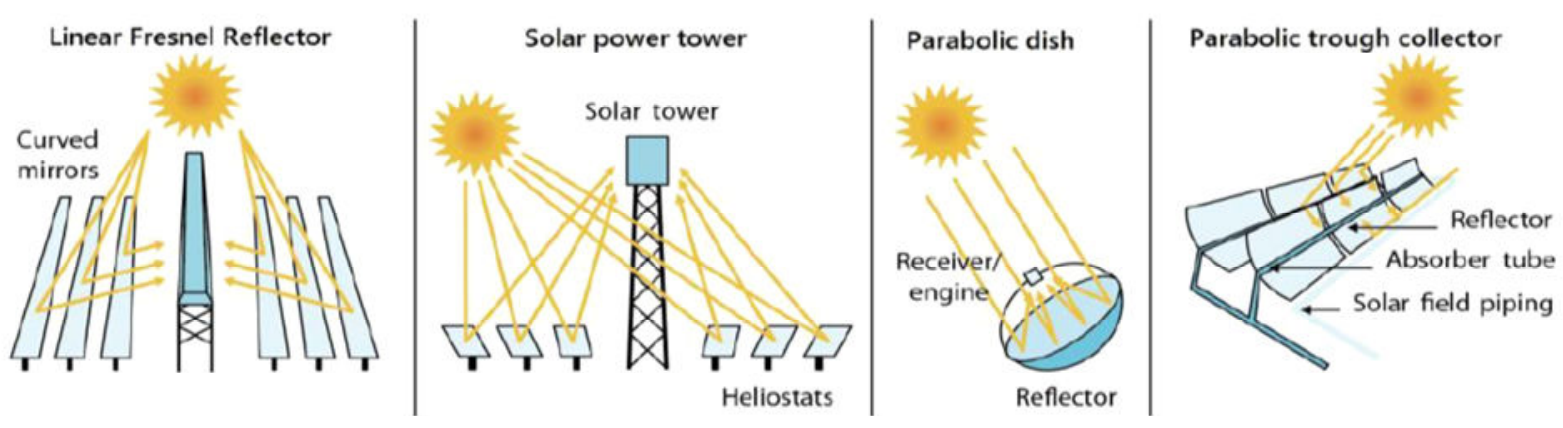

Figure 1: Different types of CSP technologies [24]

The parabolic trough collector, first demonstrated in Egypt in 1913, is currently used in $81 \%$ of operational CSP plants and in many more that are under construction [24,25].

A prototype of the Stirling parabolic dish system was successfully built in southern California between 1982 and 1985, but today most are being used only for demonstration purposes rather than commercial energy generation $[25,26]$.

The solar power tower was demonstrated for the first time in Sicily in 1965 in a project called EURELIOS. The first fully scaled-up commercial tower was the Planta Solar 10, built 40 years later in Andalusia, Spain [8,27]. The time lag between the initial research and the commercial exploitation of this heliostatic tower model might suggest some early doubts about its viability. This technology has, however, now matured and fulfilled its promising potential. In 2016, the 
installed capacity of solar power towers reached $14 \%$ of total global CSP generation (460MW) and once those currently under construction are in operation, this will rise to $28 \%$ [24].

A prototype LFR was built and demonstrated in Genoa, Italy, in 1964, but its commercial development has been slow. Currently there are only 15 commercial plants of this type worldwide and only six of them are operational $[8,25]$.

Globally, installed CSP capacity has risen from $355 \mathrm{MW}$ in 2005 to $5.5 \mathrm{GW}$ in 2018 [8,28], an average annual growth of 400 to $500 \mathrm{MW}$. The CSP industry added around $601 \mathrm{MW}$ in 2018 with projects becoming operational in Morocco, South Africa, Kuwait, Saudi Arabia and some others, but the growth rate is not accelerating noticeably [29]. Optimistic forecasts assume a 1 to $1.5 \mathrm{GW}$ annual growth, and would bring global capacity to $22.4 \mathrm{GW}$ by 2030 . But this comes nowhere near the full potential for CSP capacity by that date, which is conservatively estimated to be over $600 \mathrm{GW}[29]$.

It is clear that, despite a few positive signs, the development of the CSP industry has been and continues to be slow. This is especially the case when one compares CSP to other renewable energy technologies, such as solar photovoltaic (PV) generation (currently at $123 \mathrm{GW}$ global capacity) and wind-turbine generation (currently at $435 \mathrm{GW}$ global capacity) $[8,9,29,30]$.

Several researchers have sought to identify the reasons for this sluggish progress and the rest of this section discusses the various types of barriers they have identified.

\subsection{Main market barriers}

The literature reveals several barriers that may be slowing down the worldwide commercialisation of CSP: high initial capital costs, financial and technical risks, extensive land requirement, technological shortcomings, poor grid and service connections, institutional 
lethargy, regulatory obstacles, social opposition and cheaper competition $[1,10,11,31]$. These barriers are discussed below, together with some ways they could be overcome $[1,10,11,31]$.

\subsubsection{Techno-economic barriers}

The high capital cost of CSP is a major obstacle to its commercial development. Solar PV projects, for instance, have proven more attractive to investors because they offer better economic returns [32]. Even though the levelised cost of electricity (LCOE) generated by CSP appears to be decreasing, it is still likely to remain higher than that generated by fossil fuels and some other forms of renewable energy $[11,13,32,33]$. High capacity factors and total installed costs are both driving for the cost reduction of the CSP projects as well as LCOE. The global installed costs of CSP are decreasing each year. The global weighted average of LCOE of CSP in 2018 was $0.185 / \mathrm{kWh}$ which was $26 \%$ lower than in 2017 and $46 \%$ lower than in 2010 [34] (Figure 2).

At the same time, however, the global average capacity factor increased from $39 \%$ in 2017 to $45 \%$ in 2018. Technical advances could hugely improve the economic performance of CSP plants [35]. For example, the use of molten salts instead of thermal oils as the heat transfer fluid [31] has improved their thermal efficiency [8]. Alsagri et al. [36] have suggested that integrating molten-salt thermal energy storage into a CSP plant could reduce its LCOE by as much as $50 \%$. 


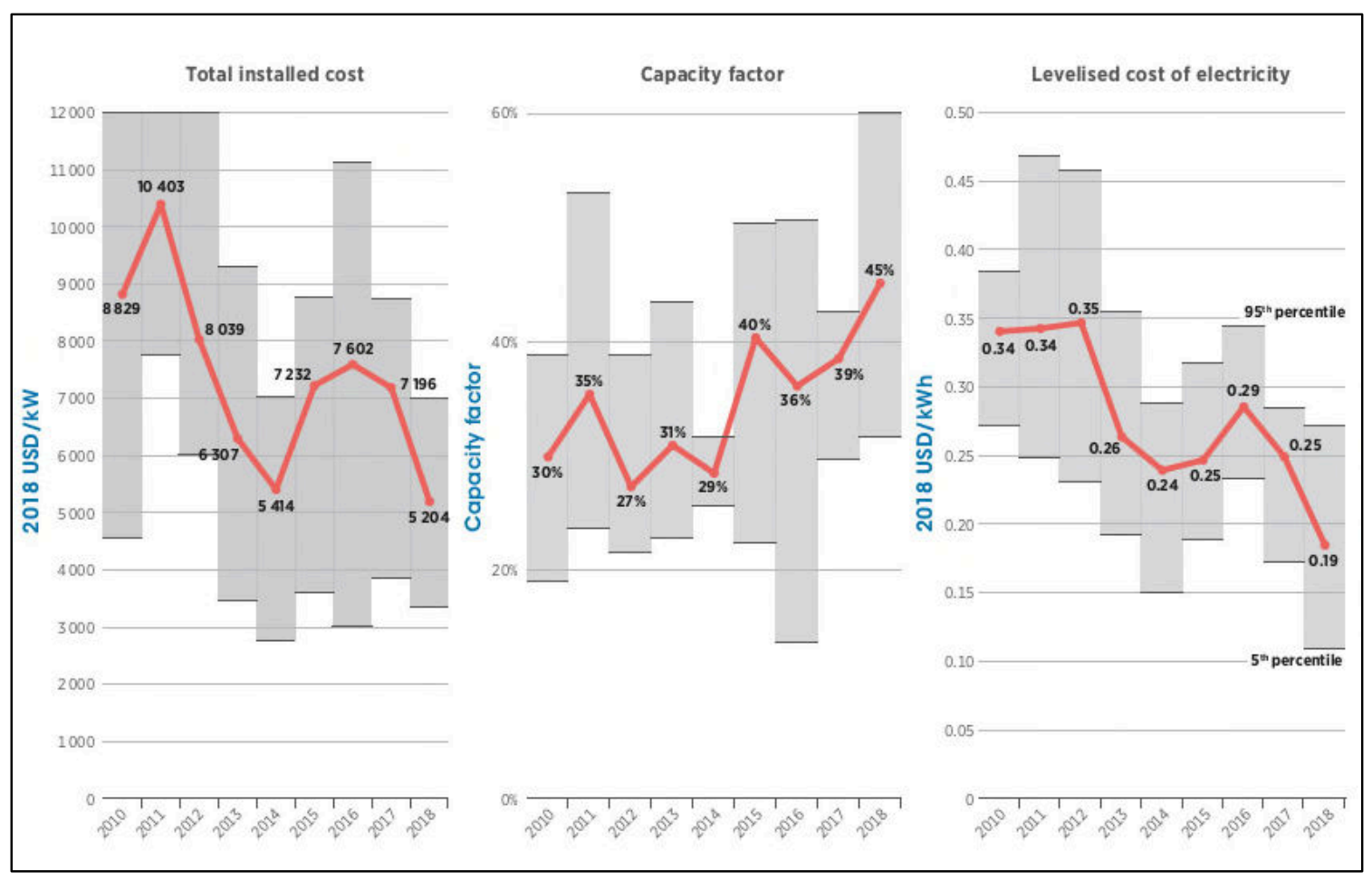

Figure 2: Global average total installed cost, capacity factor and for CSP projects from 2010 to 2018 [34]

Labordena et al. [17] argue that one of the main reasons for the high capital cost of CSP projects is that they can only be located in areas with very high solar irradiation. In practice, many CSP plants are in deserts with little industrial infrastructure, thus often needing long power lines to connect them to the grid. This makes CSP much more complex to implement than renewable energy systems that can be located close to towns and cities. However, Trieb et al. [9] point out that high voltage power lines are a cost-effective way of transmitting energy, and they note that offshore wind farms are also generally located far from towns and cities yet are a commercial success.

Another site-specific technical challenge which some have argued holds up the large-scale deployment of CSP is lack of available water for cooling the machinery that produces the electricity from the stored heat [1]. Dry-cooling technology is one solution, but it is much more expensive than water cooling [2]. 
Another site-related problem that could hold up CSP development is the large area of flat land needed for the mirror field that harvests the solar irradiation. The area needed depends on the plant's capacity, type of CSP technology, solar field and thermal storage size [12]. A CSP plant requires $20,234 \mathrm{~m}^{2}$ per megawatt of electricity produced $[31,37,38]$ and land with an average gradient of between $1 \%$ and $3 \%$; with $1 \%$ being preferable as any steeper gradient up to $3 \%$ will increase the cost of construction [12].

Khan and Arsalan [32] suggest that one of the main reasons for the prohibitive cost of CSP installation is that the technology has remained stuck for an unusually long time at the beginning of its learning curve. This prolonged immaturity has delayed the achievement of the normally expected economies of scale when prototypes are developed into larger plants. Del Río \& Kiefer [10] observe that the high cost of CSP technology in the earlier years of its development (2008-2012) was because uptake was almost entirely limited to Spain. However, looking to the future, they identify a rapidly emerging and dynamic CSP market in places like China, Chile and Morocco, with an expected cost reduction in coming years.

\subsubsection{Institutional and legal barriers}

According to Labordena et al. [17] that another major barrier to the adoption of renewables in developing countries, alongside, and to some extent exacerbating, the financial constraints, is institutional. Lack of political commitment to such large and expensive projects undermines their commercial feasibility. But there are many ways in which governments can signal their reliable support.

For a start, governments can incentivise CSP projects by guaranteeing low-risk finance. The Spanish government provided low-risk finance for several years, helping to make CSP projects attractive to investors and successfully establishing Spain as a world-leader in the technology 
[39]. The Spanish government reversed this policy in 2013, resulting in uncertainty that led to a slowdown. By contrast, the Italian government has recently signalled its ongoing support for CSP plants by introducing a Feed-in-Tariff (FiT) to encourage them [13]. Overall, the main driver for CSP uptake is government subsidies, including FiT.

In addition to financial risk and legal and administrative barriers, such as difficulties in securing land and water rights, can limit the deployment of CSP plants. Del Río et al. [13] say one of the main problems in Italy and Greece is the over-complexity of the planning permission process. Italian environmental regulations also do not allow the use of oil in CSP plants, which limits the technological options.

\subsubsection{Social acceptance}

Among the environmental impacts of CSP plants that have led to social opposition [40], such as interference with land and agricultural usage, the most commonly cited are high water consumption and reduction of biodiversity [41-43]. During the construction of the Ouarzazate Solar Power Station in Morocco, or Noor 1, the world's largest concentrated solar power plant, there were several protests over the diversion of water resources from nearby villages $[43,44]$. However, the literature indicates that the protests were not major, and according to Hanger et al.[45] $91 \%$ of the community in the region of the plant were strongly in favour of CSP projects.

Visual intrusion is another common complaint made by the general public. Tower CSP plants are conspicuous features on the horizon. In contrast, PTC plants are much less obtrusive despite occupying large areas of land that cause changes to the landscape [46]. Given that these plants are usually in arid locations far from towns and cities, it can hardly be claimed that they represent a major eyesore [46]. More serious than visual intrusion is the risk to birds, from injury or death caused by colliding with CSP plant infrastructure or being burnt by concentrated 
solar flux [40,41]. Collisions may occur when the structures are invisible or confusing to birds. According to Otieno and Loosen [41] collisions with the parabolic trough plants are more likely to happen when birds mistake surface reflections for sky or water, and that burning from flux streams may be more frequent with tower plants [41]. However, both Otieno and Loosen [41] and Walston et al. [47] say the number of bird fatalities caused by CSP plants is not remarkable in comparison with other causes.

Besides water consumption, visual intrusion and the threat to birds, land occupancy is another common cause of public opposition. As land may have religious, symbolic and cultural value for some communities, installing CSP plants without careful planning could lead to conflict [43,48]. In 2010, the Moroccan government's purchase of 3,000 ha of collectively owned land for the development of Noor 1 caused several protests as the land had historical significance [49].

Wenzlawski and Tol [11], however, argue that most of the barriers to CSP progress are manageable or avoidable, so the question of why CSP is developing so slowly remains largely unanswered.

\section{Strategic niche management}

The transition to a low carbon energy system requires many changes, not just from the consumers' side but also in government policies and technical approaches [21]. Radical innovations and sustainable technologies can be developed in specialised areas called 'niches' $[22,50]$, which can stimulate systemic change [21,51]. Strategic niche management (SNM) is the process of managing niche formation through real-life experiments [52]. It can be a way of bridging the so-called 'valley of death' between research and development (R\&D) and the market [53]. 
SNM seeks to understand and to foster the socio-economic and technological process by which such transitions occur. It provides a theoretical framework for the successful introduction of innovations that are necessary to achieve long-term social objectives such as sustainability, but which require radical novelties which conflict with existing infrastructure, policy and practice $[22,53,54]$.

As a research tool for understanding transition, SNM looks back at the history of recent experiments in technological change to identify the conditions that foster or hinder the development of successful niches [52,53]. As a policy tool for fostering transition [53,54], it has been used to evaluate or encourage the introduction of new technology, such as solar energy in developing countries [21] and community-owned renewable energy projects in the UK [55]. However, it is not without its critics. Caniëls and Romijn [54] argue that although it has proven useful in analysing the outcomes of experiments in introducing renewable energy technologies, such as wind turbines biogas plants and electric vehicles, its track record as an authoritative guide to policy is less convincing. Elmustapha et al. [21] suggest that one reason for this may be that the success of niches depends on the local geography and culture, so SNM needs to sensitive to context.

Kemp et al.[56] state three critical conditions that must be satisfied for a niche to be successful: expectations must be defined and voiced, supportive social networks must be built, and a learning process must occur.

When SNM is applied to the introduction of renewable energy technology niches, supportive regulatory structures (such as subsidies) are very important because such niches can suffer from a high degree of instability and a lack of sufficient market demand [21]. The following subsections examine these niche conditions in more detail. 


\subsection{Expectations}

Expectations play an important in promoting radical innovations with uncertain outcomes [57], particularly in the earliest phases of the technological innovation process [58]. The concept of expectations as the main element of technological innovation has been developed into the sociology of expectations by Borup et al.[57].

Sometimes consumers select a technology on the basis of facts, specifications of its practicality, and its economic variations. In the case of emerging innovative technologies, investment decisions have to be taken into consideration at an early stage of the development [58]. Technological innovations are most likely to be adopted and coordinated when consumers voice their expectations and receive a response. Adoption is likely when expectations are standard reference points for the actors at different levels of technology development [58,59].

The voicing of positive expectations and an optimistic view of a new technology are crucial for successful niche development [60], especially in the case of radical innovations with uncertain outcomes. Expectations play an essential role in recruiting new actors and motivating them to learn $[21,61,62]$, and they can also be used strategically to attract resources and funding [63]. Schot and Geels [53] believe they are most effective when they are shared by a large number of actors and are transparent and convincingly feasible and backed by experimental results.

\subsection{Social networks}

Social networks can play a vital role in niche formation and maintenance, by enabling actors to exchange views. Social networks can be built on both formal and informal platforms, including government organisations and conferences. They are most effective if they have a wide diversity of actors, including manufacturers, users, investors, policymakers and 
regulators. The livelier the interaction between them the better [21,64]. Opazo [20] notes that resources to support the platform must be available.

\subsection{Learning}

According to Schot \& Geels [53], learning is essential because it enables changes in cognitive paradigms, leading the actors to adjust either the niche's central technology or the social context in which the technology is adopted. If new technology is simply pushed with no acknowledgement of the need for adaptive learning, then the market may fail to take account of unforeseen changes in consumer behaviour. This is where the key SNM concept of a niche as a social experiment is so important [21,54]. Schot and Geels [53] argue that learning needs to occur in multiple dimensions: technical aspects and design specifications, market and user preferences, social and environmental effects, and regulation and government policy.

Geels and Deuten [65] have explored the way that niches are initiated from a socio-cognitive perspective. They observe that niche development is a non-linear process comprised of four phases: local, inter-local, trans-local and global (Figure 3).

During the local phase, the new technology is often associated with a small specific project and knowledge exchange takes place mainly through word of mouth. In the inter-local phase, the interactive space expands so that technical knowledge can be exchanged. However, the knowledge remains locked within the network and is rarely disclosed to external actors. It is not until the trans-local phase that knowledge begins to circulate more widely, for example through the distribution of handbooks and articles. Another characteristic of this stage is the emergence of intermediary actors and platforms such as organisations of workshops and conferences. As niches move towards the final (global) phase, they become more stable, and the knowledge circulating within them comes to be regarded as 'general' and therefore 
appropriate for sharing with broader society. The transition is finally complete when the shared knowledge is fully universalised and the boundaries of the niche lose their relevance.

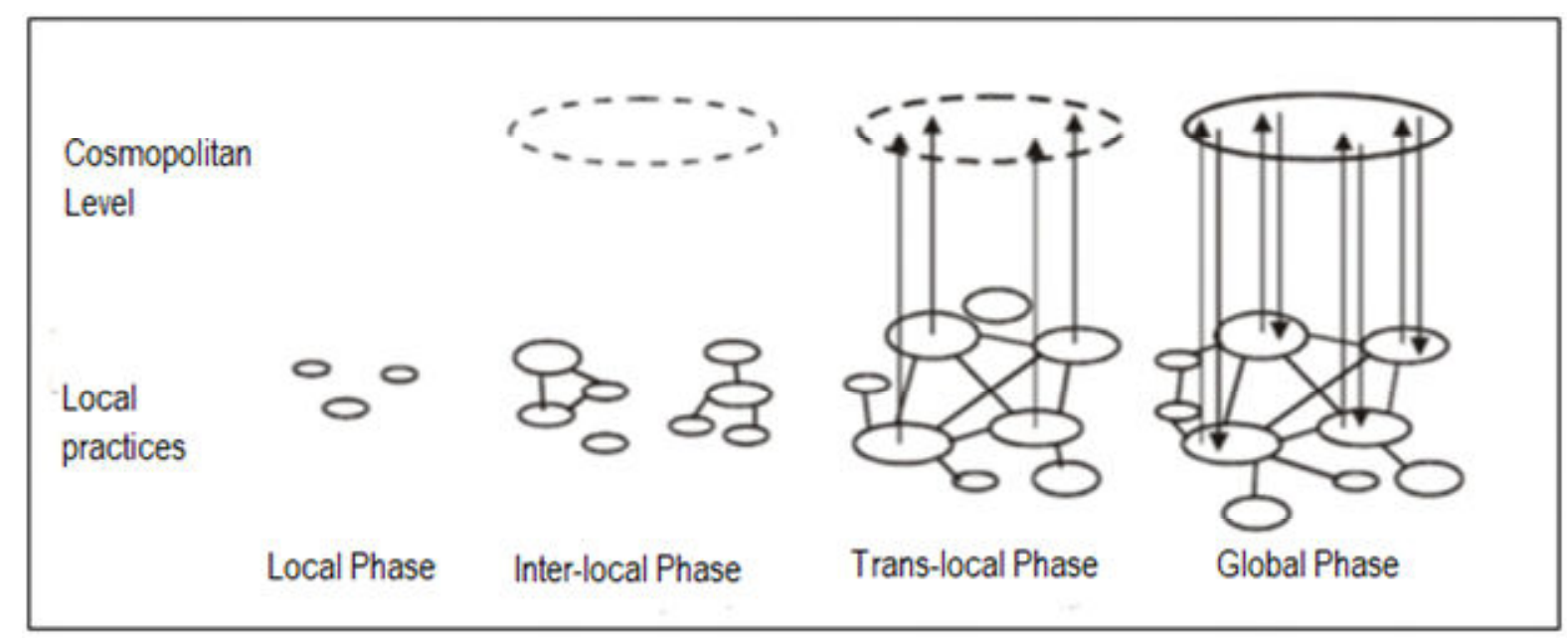

Figure 3: Four phases of technological knowledge sharing [65]

\section{Method}

In this study, we used Kemp's three conditions for a successful niche (expectations must be defined and voiced, supportive social networks must be built, a learning process must occur) to analyse the diffusion of CSP in the US (California) and South Africa, two countries that stand in sharp contrast in the CSP industry. The US, a pioneer in the industry, has a long history of developing CSP plants. South Africa is just a beginner, despite enjoying some of the world's highest levels of sunshine (calculated as direct normal irradiation, or DNI) [12].

Figure 4 shows how we used Kemp's conditions to evaluate the formation of CSP niches in these two countries. By comparing the two, we were able to identify factors involved in the successful emergence of CSP. The SNM framework enabled us to make a more in-depth analysis of the dynamics within a CSP-promoting socio-technical niche. We could then recommend some ways to foster the development and diffusion of CSP. 


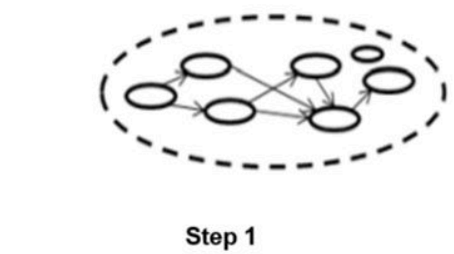

Conducting desk-based academic and policy literature review to identify the main drivers of shaping expectation in CSP projects

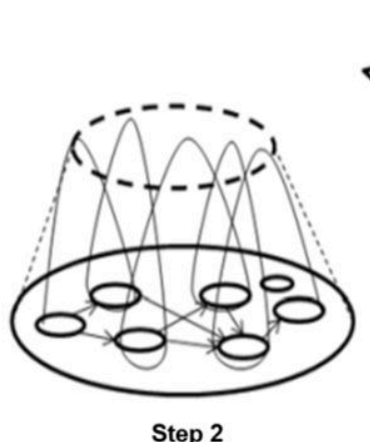

Step 2

Evaluating the role of actors in the development of CSP projects

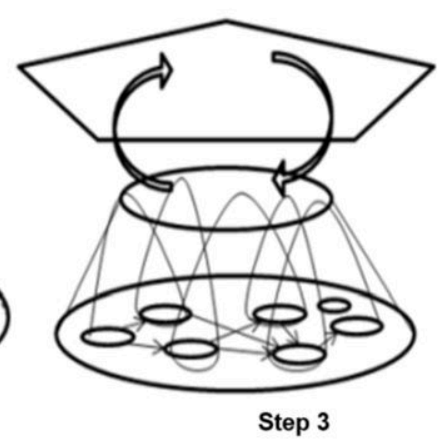

Evaluating the process of learning and knowledge exchange in the development of CSP projects

Through reviewing 3 case studies evidence which was primarily collected via secondary data including official reports and archival records of the project database.

Figure 4: using internal niche process for evaluating CSP niche formation; adapted from [65]

Our evidence came from a desk-based review of academic and policy literature, including journals, government papers, official reports and archival records from projects' databases. We investigated three CSP plants in particular, two in California and one in South Africa: the Ivanpah CSP at Ivanpah Dry Lake, California (392 MW); the Solar Energy Generating Systems (SEGS) in California's Mojave Desert, which consists of nine CSP plants (354MW); and the Bokpoort CSP in South Africa's Northern Cape Province (50 MW).

We selected SEGS because it was the first commercial CSP project in the world [66] and the largest until 2014 when Ivanpah CSP overtook it, and the Bokpoort CSP because of data availability and its unique financing structure.

\section{Results}

The purpose of this study was to identify the key factors in the successful development of the CSP industry in the US and the reasons for its comparatively sluggish growth in South Africa. These lessons should help to accelerate the global uptake of CSP projects. 
Sections 5.1 and 5.2 provide an overview of the energy market and the CSP industry in the US and explore the process of niche development in that country, and Sections 5.3 and 5.4 do the same for South Africa.

\subsection{Overview of the energy market in the US}

The US contains both competitive and vertically integrated electricity markets, (i.e. the utilities use their generation, transmission and distribution systems to deliver electricity to consumers) [67]. In some parts of the US, however, including much of the Northeast, Midwest, Texas and California, the market has been restructured to allow independent power producers and nonutility generators to trade electricity, thus encouraging competition [68].

Solar energy (both PV and CSP) contributes to a growing proportion of the electricity consumed in the US. There are currently 15 active CSP plants, representing $1.7 \mathrm{GW}(60 \%)$ of the $5.5 \mathrm{GW}$ of total installed capacity worldwide (see Figure 5). It is estimated that the potential for further development of CSP in the US is $118 \mathrm{GW}$ by 2030, rising perhaps to 2504GB by 2050 [69].

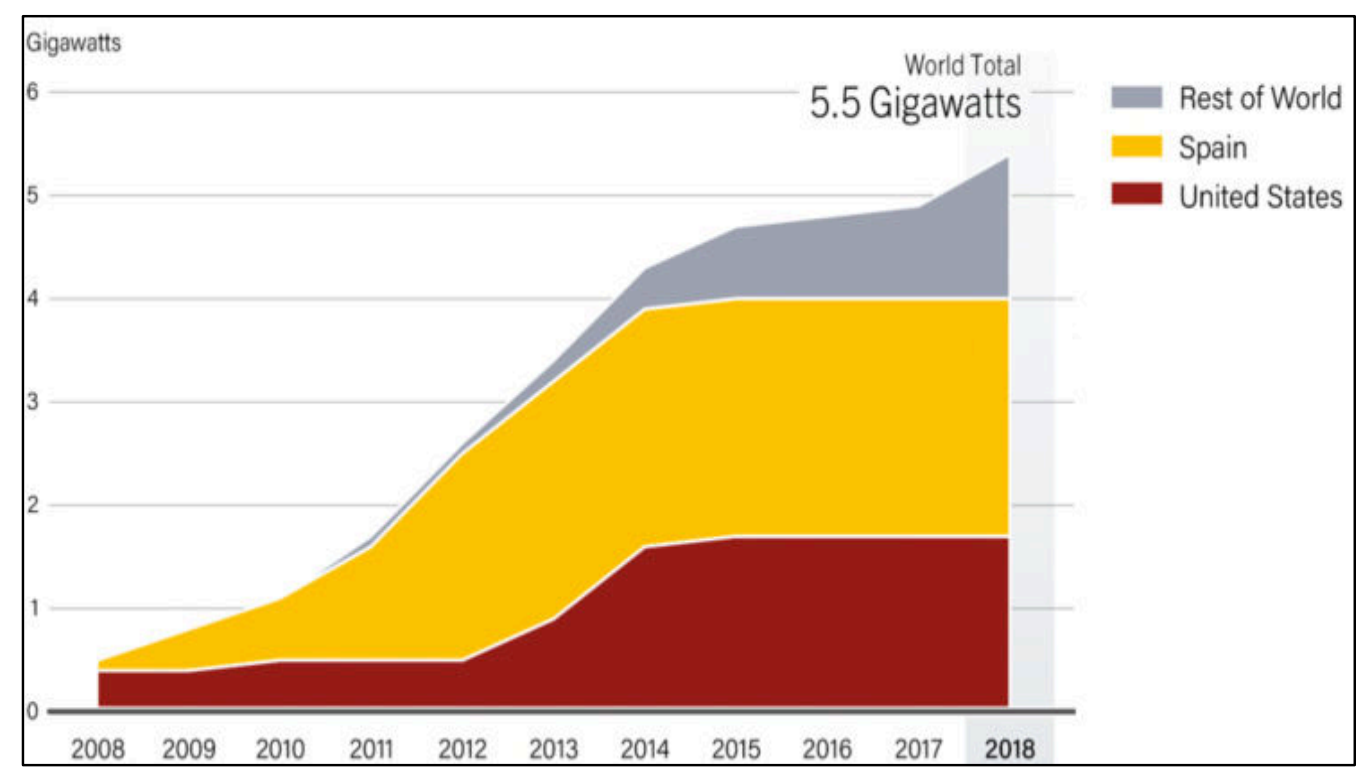

Figure 5: CSP global capacity by country, 2008-2018 [28] 
SEGS I, installed in 1984, represented the first commercial exploitation of CSP in the world [66] and until 2014 it was the largest $[69,70]$. SEGS now has nine CSP plants (SEGS I-SEGS IX), located at three different sites. The main aim of SEGS I was to evaluate the parabolic trough collector's ability to generate electricity and to assess the efficiency of the first type of heat element [25]. Between 1985 and 1990, LUZ Industries constructed a further series of commercial with an overall capacity of $354 \mathrm{MW}$ in the Mojave Desert, California, US (see Table 1). However, when the oil price dropped in the 1990s, the US government reduced its support for alternative energy and there was no further construction of CSP until 2006 when government funding was restored (Table 1). 
Table 1: CSP plants implemented in the US; compiled from [16]

\begin{tabular}{|c|c|c|c|c|c|c|}
\hline Plant Name & Location & $\begin{array}{l}\text { Year of } \\
\text { operation }\end{array}$ & Project type & Project Status & Technology & $\begin{array}{l}\text { Project } \\
\text { capacity }\end{array}$ \\
\hline SEGS I & California & 1984 & Commercial & Decommissioned & $\begin{array}{l}\text { Parabolic } \\
\text { Trough }\end{array}$ & $13 \mathrm{MW}$ \\
\hline SEGS III & California & 1985 & Commercial & Decommissioned & $\begin{array}{l}\text { Parabolic } \\
\text { Trough }\end{array}$ & $30 \mathrm{MW}$ \\
\hline SEGS III & California & 1985 & Commercial & Operational & $\begin{array}{l}\text { Parabolic } \\
\text { Trough }\end{array}$ & $30 \mathrm{MW}$ \\
\hline SEGS IV & California & 1989 & Commercial & Operational & $\begin{array}{l}\text { Parabolic } \\
\text { Trough }\end{array}$ & $30 \mathrm{MW}$ \\
\hline SEGS V & California & 1989 & Commercial & Operational & $\begin{array}{l}\text { Parabolic } \\
\text { Trough }\end{array}$ & $30 \mathrm{MW}$ \\
\hline SEGS VI & California & 1989 & Commercial & Operational & $\begin{array}{l}\text { Parabolic } \\
\text { Trough }\end{array}$ & $30 \mathrm{MW}$ \\
\hline SEGS VII & California & 1989 & Commercial & Operational & $\begin{array}{l}\text { Parabolic } \\
\text { Trough }\end{array}$ & $30 \mathrm{MW}$ \\
\hline SEGS VIII & California & 1989 & Commercial & Operational & $\begin{array}{l}\text { Parabolic } \\
\text { Trough }\end{array}$ & $80 \mathrm{MW}$ \\
\hline SEGS IX & California & 1990 & Commercial & Operational & $\begin{array}{l}\text { Parabolic } \\
\text { Trough }\end{array}$ & $80 \mathrm{MW}$ \\
\hline Saguaro Power Plant & Arizona & 2006 & Demonstration & $\begin{array}{l}\text { Currently non- } \\
\text { Operational }\end{array}$ & $\begin{array}{l}\text { Parabolic } \\
\text { Trough }\end{array}$ & $1 \mathrm{MW}$ \\
\hline Nevada Solar One & Nevada & 2007 & Commercial & Operational & $\begin{array}{l}\text { Parabolic } \\
\text { Trough }\end{array}$ & $75 \mathrm{MW}$ \\
\hline Holaniku at Keahole Point & Hawaii & 2009 & Demonstration & $\begin{array}{l}\text { Currently non- } \\
\text { Operational }\end{array}$ & $\begin{array}{l}\text { Parabolic } \\
\text { Trough }\end{array}$ & $2 \mathrm{MW}$ \\
\hline $\begin{array}{l}\text { Colorado Integrated Solar } \\
\text { Project }\end{array}$ & Colorado & 2010 & Demonstration & $\begin{array}{l}\text { Currently non- } \\
\text { Operational }\end{array}$ & $\begin{array}{l}\text { Parabolic } \\
\text { Trough }\end{array}$ & $2 \mathrm{MW}$ \\
\hline $\begin{array}{l}\text { Maricopa Solar Project } \\
\text { (Maricopa) }\end{array}$ & Arizona & 2010 & Demonstration & $\begin{array}{l}\text { Currently non- } \\
\text { Operational }\end{array}$ & Dish & $1.5 \mathrm{MW}$ \\
\hline $\begin{array}{l}\text { Martin Next Generation } \\
\text { Solar }\end{array}$ & Florida & 2010 & Commercial & Operational & $\begin{array}{l}\text { Parabolic } \\
\text { Trough }\end{array}$ & $75 \mathrm{MW}$ \\
\hline \multicolumn{7}{|l|}{ Energy Centre } \\
\hline Solana & Arizona & 2013 & Commercial & Operational & $\begin{array}{l}\text { Parabolic } \\
\text { Trough }\end{array}$ & $250 \mathrm{MW}$ \\
\hline Tooele Army Depot & Utah & 2013 & Commercial & $\begin{array}{l}\text { Currently non- } \\
\text { Operational }\end{array}$ & Dish & $1.5 \mathrm{MW}$ \\
\hline $\begin{array}{l}\text { Genesis Solar Energy } \\
\text { Project }\end{array}$ & California & 2014 & Commercial & Operational & $\begin{array}{l}\text { Parabolic } \\
\text { Trough }\end{array}$ & $250 \mathrm{MW}$ \\
\hline $\begin{array}{l}\text { Ivanpah CSP } \\
\text { Generating System }\end{array}$ & California & 2014 & Commercial & Operational & Power Tower & 392 MW \\
\hline Mojave Solar Project & California & 2014 & Commercial & Operational & $\begin{array}{l}\text { Parabolic } \\
\text { Trough }\end{array}$ & $250 \mathrm{MW}$ \\
\hline $\begin{array}{l}\text { Crescent Dunes Solar } \\
\text { Energy Project }\end{array}$ & Nevada & 2015 & Commercial & Operational & Power Tower & $110 \mathrm{MW}$ \\
\hline $\begin{array}{l}\text { Stillwater GeoSolar Hybrid } \\
\text { Plant }\end{array}$ & Nevada & 2015 & Commercial & Operational & $\begin{array}{l}\text { Parabolic } \\
\text { Trough }\end{array}$ & $2 \mathrm{MW}$ \\
\hline
\end{tabular}


Today, $70 \%$ of the total installed capacity of CSP in the US is located in California, including Ivanpah CSP which was the world's largest plant in 2014. Figure 6 shows California's exceptional solar resources, all this sunlight being a major factor in the success of CSP in this state.

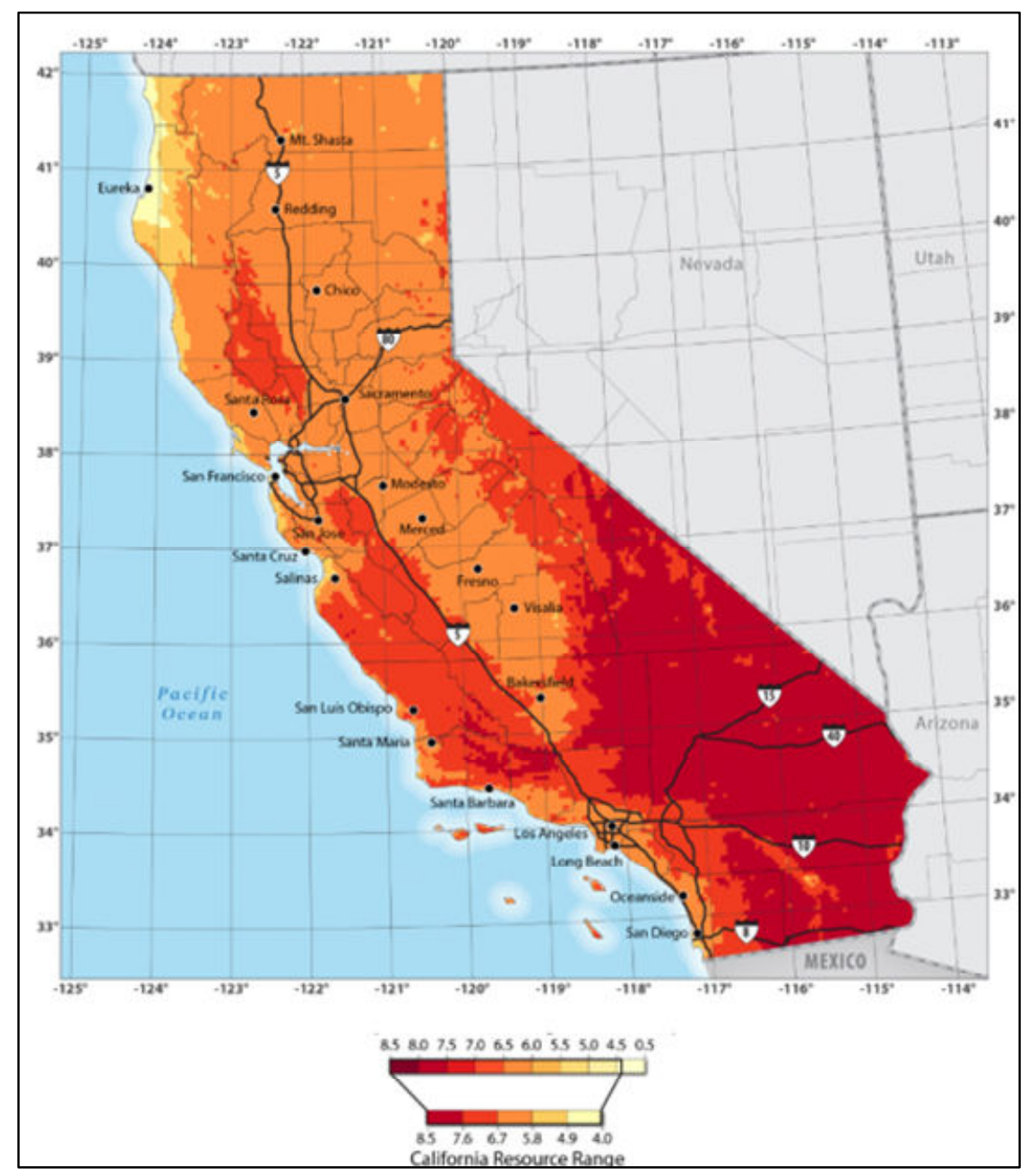

Figure 6: Solar resources in California [71]

\subsection{Internal niche process}

The factors fostering the development of CSP plants in the US were investigated using Kemp's et al. [56] SNM framework. 


\subsubsection{Role of policy support in shaping expectations in the US}

The US Department of Energy (DOE) has supported the research and development of CSP over nearly four decades. This government sponsorship has been vital in inspiring positive and optimistic expectations. The time-line in Figure 7 shows the consistency of the encouragement that has been offered right up to the present day. The CSP demonstration projects (SEGS I to IX) were funded by the Department of Energy in the 1980s and became the prototype for most of the later CSP projects [72]. Further encouragement was provided in the 1990s when the US Congress introduced a $10 \%$ investment tax credit to support the industry. When it became clear that this incentive was not sufficient to stimulate private investment, the investment tax credit was increased to $30 \%$ by the 2005 Energy Act [73].

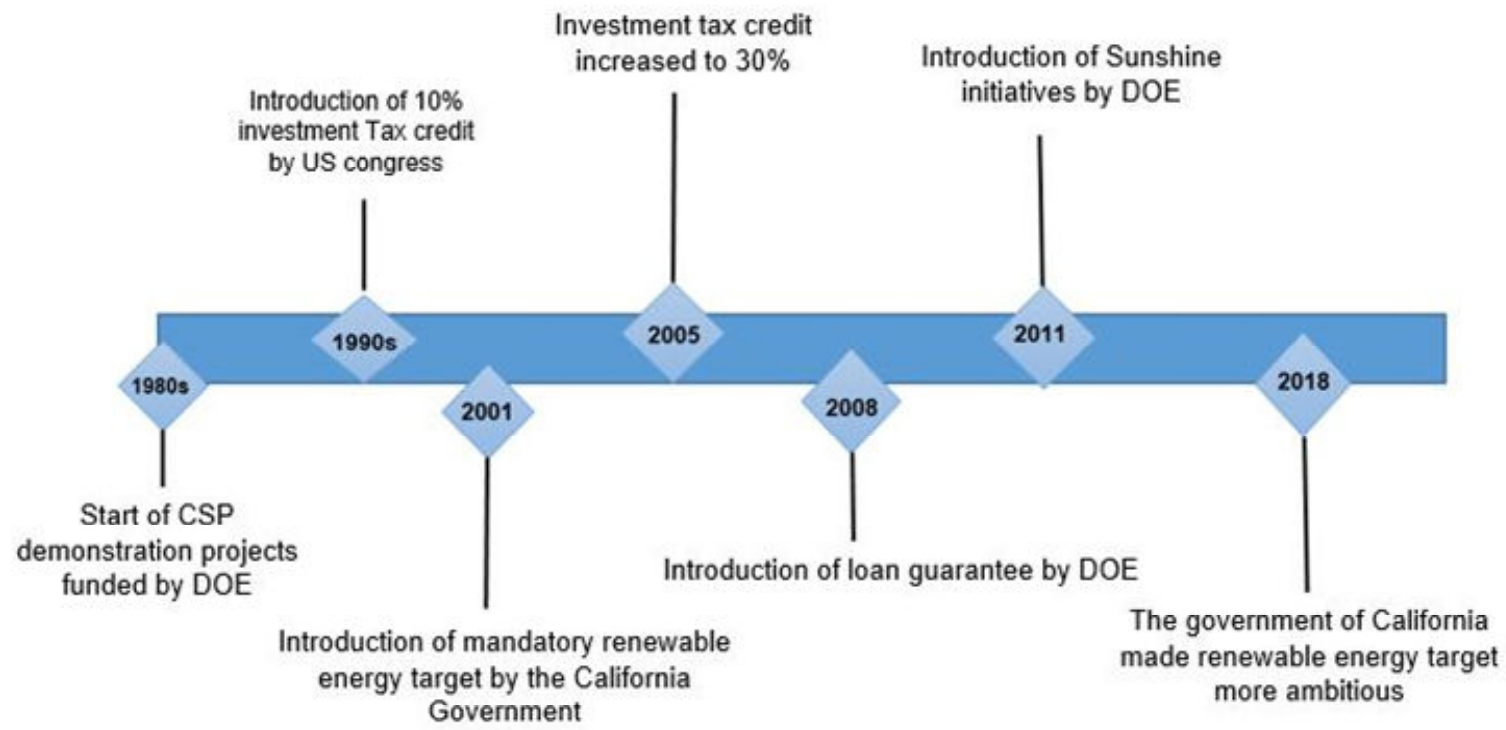

Figure 7: Historical overview of key support schemes for CSP niches in California; compiled from [73-76] 
In 2001, the state of California introduced mandatory targets for installing renewable energy plants and reducing carbon emissions. This bold initiative undoubtedly reinforced expectations for CSP.

In 2008 the Department of Energy introduced a loan guarantee programme to provide lowinterest finance for CSP projects that had been proven to be viable but had not yet been commercially exploited. This programme provided a significant opportunity for CSP niches to bridge the so-called 'valley of death', the critical period between research and development and the emergence of supported CSP niches in the market [72]. And in 2011 the Department of Energy introduced the SunShot initiative to support the development of early-stage technologies, offering a $75 \%$ reduction in the cost of project development [74].

The Ivanpah CSP project was the first commercial tower CSP built in the US and is currently the world's biggest operational CSP plant. It was developed by BrightSource Energy on public land in the Mojave Desert. The Department of Energy issued three loan guarantees totalling $\$ 1.6$ billion in support of this $\$ 2.2$ billion project [72], reducing the financial risk to a level that was acceptable to private investors.

The State of California's commitment to the development of renewable energy continues to be exemplary. In 2018 it increased its already ambitious targets, requiring that $50 \%$ of the state's electricity should come from low-carbon-emitting sources by $2025,60 \%$ by 2030 and $100 \%$ by 2045 [75]. Coupled with the Department of Energy's generous financial guarantees and tax incentives, this support has enabled CSP niches to emerge in the market [76] successfully.

\subsubsection{Role of social networks in the development of CSP industry in the US}

In the 1980s the social network of CSP niches started small, with the Department of Energy and Luz Industries (now BrightSource Energy). In the early stage of CSP development the 
financial risk associated with these projects was high, so it was not easy to engage stakeholders. However, the funding schemes which were designed to support CSP developments helped to overcome this initial reluctance and promote niche formation. Our case studies show that funding schemes in the US helped networks of actors to diversify and grow and bring in new actors. In the case of the Ivanpah CSP plant, for instance, the funding from the loan guarantee programme encouraged large companies, including Google, NGR and BrightSource, to invest [72]. Our analysis indicates that support from private companies through their social networks was critical in promoting niche stability and successful diffusion of CSP in California.

\subsubsection{Role of learning in the diffusion of CSP in the US}

Analysis of reports from the SEGS projects indicates that their sequential development between 1984 and 1990 undoubtedly encouraged knowledge exchange. Some of the most effective learning happened at the 'trans-local phase' when SEGS demonstration projects helped to diffuse expertise in solving technical problems. The lessons learnt from SEGS I to VII were how to optimise the technical performance of CSP and what the best conditions were for developing CSP projects in the US, and SEGS VIII to XI showed how to increase parabolic trough efficiency and thereby to decrease the cost per $\mathrm{kW}$ of the generated electricity [25]. This techno-economic learning was also transferred from SEGS to other similar projects, encouraging the diffusion of CSP niches and eventually the broader commercialisation of the technology. Our analysis leads us to conclude that the CSP industry in California has now entered the 'global' phase (see Figure 3), which means that the expertise it has developed is being shared around the world. 


\subsection{Overview of the energy market in South Africa}

The South African energy market is vertically integrated and extremely centralised, with around $70 \%$ of its total primary energy consumption coming from coal power stations managed by Eskom, the national utility [77]. Eskom currently generates about 44GW of electricity, and this is expected to increase to $84 \mathrm{GW}$ by 2025 to meet increasing domestic and industrial demand [78].

The country's reliance on coal poses the dilemma of how its energy security can be maintained and at the same time fulfil its commitment to the Paris Agreement on climate change. Radical change within the entire energy system is urgently needed $[5,79]$.

South Africa has some of the best solar resources in the world (see Figure 8), so there is an excellent opportunity for it to meet much of its energy demand using CSP power generation. The country has the potential to accommodate CSP projects producing a total of over 500GW [17]. Despite this, until very recently no CSP plants had been installed at all. The Introduction of Renewable Energy Independent Power Producer Procurement Programme of 2011, which was designed to promote private investment in renewable energy, improved the situation a little. However, there are still only seven CSP power plants in the country, with an overall capacity of $600 \mathrm{MW}$. Six of these projects are operational and one is under development (see

\begin{tabular}{|c|c|c|c|c|c|c|}
\hline Plant name & Location & $\begin{array}{l}\text { Year of } \\
\text { operation }\end{array}$ & Project type & Project status & Technology & $\begin{array}{l}\text { Project } \\
\text { capacity }\end{array}$ \\
\hline
\end{tabular}




\begin{tabular}{|c|c|c|c|c|c|c|}
\hline $\begin{array}{l}\text { KaXu Solar } \\
\text { One }\end{array}$ & Pofadder & 2015 & Commercial & Operational & Parabolic trough & $100 \mathrm{MW}$ \\
\hline Bokpoort & Groblershoop & 2016 & Commercial & Operational & Parabolic trough & $50 \mathrm{MW}$ \\
\hline Khi Solar One & Upington & 2016 & Commercial & Operational & Power Tower & $50 \mathrm{MW}$ \\
\hline Xina Solar One & Pofadder & 2017 & Commercial & Operational & Parabolic trough & $100 \mathrm{MW}$ \\
\hline $\begin{array}{l}\text { Kathu Solar } \\
\text { Park }\end{array}$ & Kuruman & 2019 & Commercial & Operational & Parabolic trough & $100 \mathrm{MW}$ \\
\hline Ilanga I & Kimberley & --------- & Commercial & Operational & Parabolic trough & $100 \mathrm{MW}$ \\
\hline Redstone CSP & Postmasburg & ---------- & Commercial & Under development & Power Tower & $100 \mathrm{MW}$ \\
\hline Total & --------' & --------- & --------- & --------- & 7 & $600 \mathrm{MW}$ \\
\hline
\end{tabular}

Table 2: CSP plants implemented in South Africa [16] 
) .

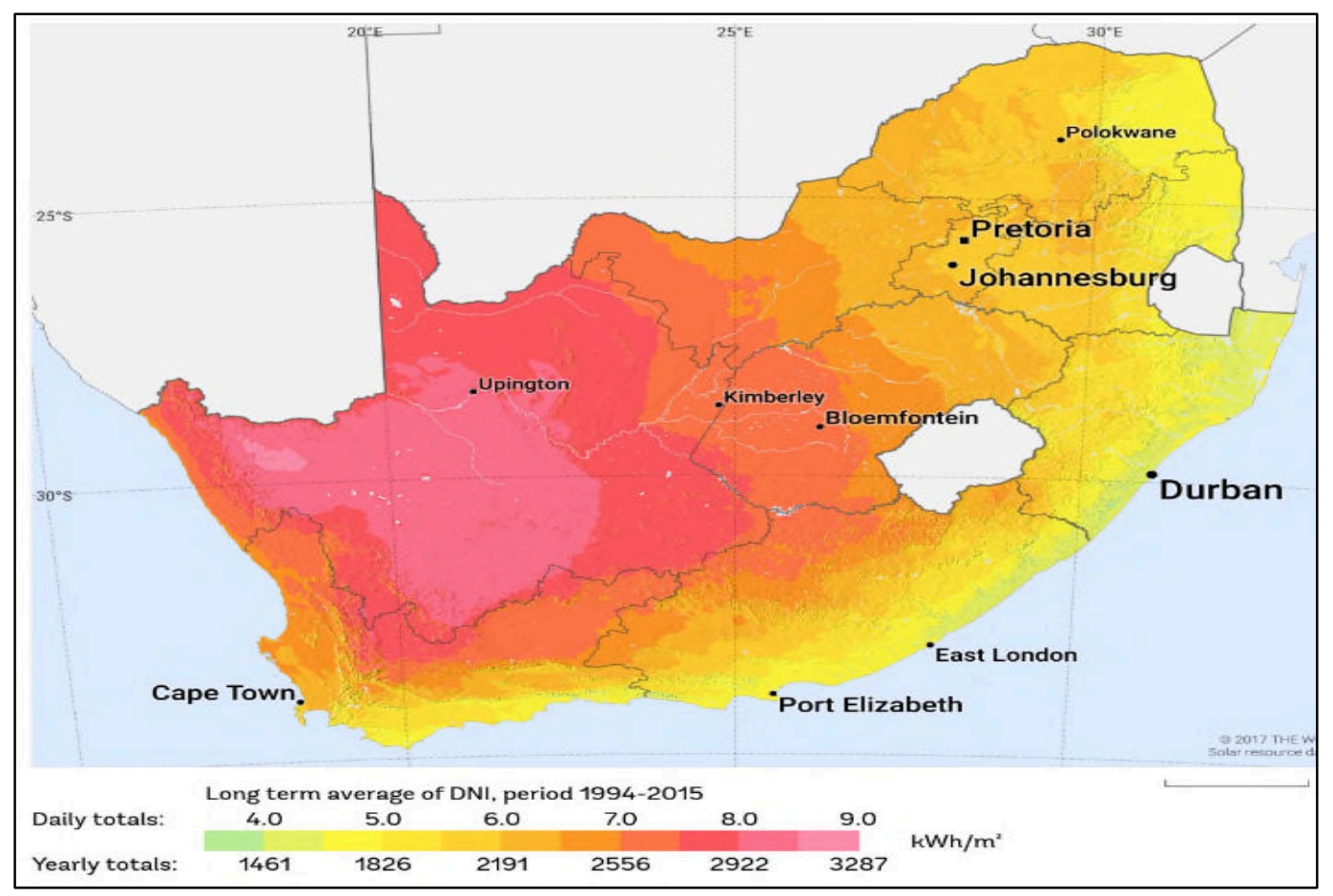

Figure 8: Solar resources in South Africa [80]

Table 2: CSP plants implemented in South Africa [16]

\begin{tabular}{|c|c|c|c|c|c|c|}
\hline Plant name & Location & $\begin{array}{l}\text { Year of } \\
\text { operation }\end{array}$ & Project type & Project status & Technology & $\begin{array}{l}\text { Project } \\
\text { capacity }\end{array}$ \\
\hline $\begin{array}{l}\text { KaXu Solar } \\
\text { One }\end{array}$ & Pofadder & 2015 & Commercial & Operational & Parabolic trough & $100 \mathrm{MW}$ \\
\hline Bokpoort & Groblershoop & 2016 & Commercial & Operational & Parabolic trough & $50 \mathrm{MW}$ \\
\hline Khi Solar One & Upington & 2016 & Commercial & Operational & Power Tower & $50 \mathrm{MW}$ \\
\hline Xina Solar One & Pofadder & 2017 & Commercial & Operational & Parabolic trough & $100 \mathrm{MW}$ \\
\hline $\begin{array}{l}\text { Kathu Solar } \\
\text { Park }\end{array}$ & Kuruman & 2019 & Commercial & Operational & Parabolic trough & $100 \mathrm{MW}$ \\
\hline Ilanga I & Kimberley & -------- & Commercial & Operational & Parabolic trough & $100 \mathrm{MW}$ \\
\hline Redstone CSP & Postmasburg & --------- & Commercial & Under development & Power Tower & $100 \mathrm{MW}$ \\
\hline Total & 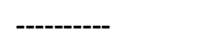 & ----------ני & 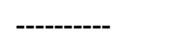 & 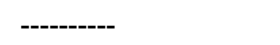 & 7 & $600 \mathrm{MW}$ \\
\hline
\end{tabular}




\subsection{The internal niche development process in South Africa}

The reasons for the slow development of CSP plants in South Africa were investigated using Kemp's SNM framework.

\subsubsection{Role of policy support in shaping expectations in South Africa}

The time-line in Figure 9 tracks the measures introduced by the South African government to promote renewable energy. The story began in 1998, when it published a White Paper aimed at reducing energy-related environmental impacts. However, renewable energy played a negligible role in meeting the associated targets due to high upfront costs [81]. In 2002 the government approved a National Integrated Resource Plan (NIRP) designed to enable South Africa to optimise the way the country met its electricity demands [82]. However, none of the NIRP policies was explicitly focused on renewable energy. A year later, a second White Paper was produced which for the first time explicitly promoted renewable energy technologies, setting the modest target that $4 \%$ of total electricity generation should be obtained from biomass, wind, solar and small-scale hydro projects by 2013 [83,84]. Nakumuryango and Inglesi-Lotz [82] argue that a more ambitious long-term renewable energy target was required. Nevertheless, at least to a limited extent, the 2003 paper aroused expectations for the solar energy industry. In 2007, these expectations were further encouraged when the government identified CSP as one of the most promising potential components in the South African energy mix [84]. However, mere rhetoric was not enough to overcome the many obstacles that confronted any CSP project, especially the high capital cost and the associated commercial risks [85]. 
The first financial incentive offered to CSP came in 2009 when the South African government adopted the Renewable Energy Feed-In-Tariff (REFIT) programme to support the 4\% renewable energy target it had agreed on six years earlier. This scheme fixed a guaranteed price for electricity production from a wide range of renewable energy technologies (including CSP), thus reducing the risk and uncertainty associated with such projects by providing a stable revenue stream and return on investment for a fixed period [86].

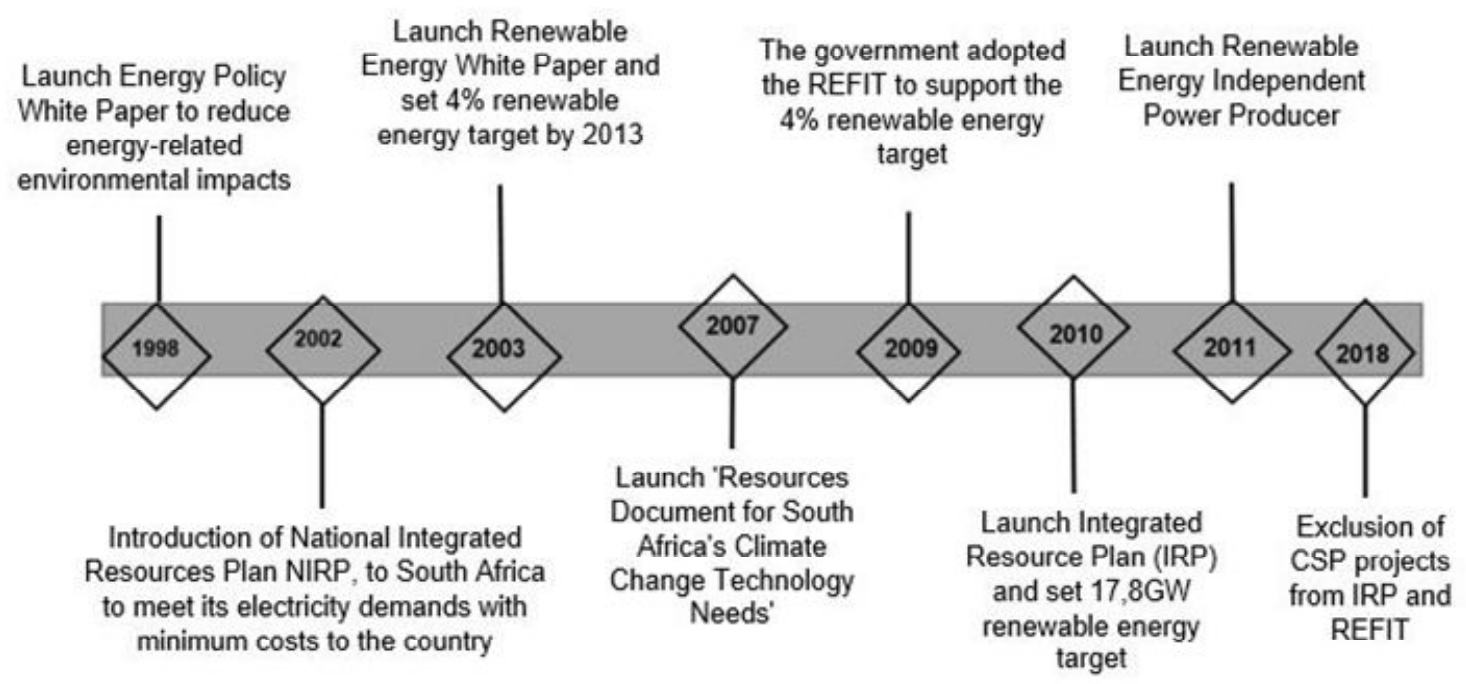

Figure 9: Historical overview of key support schemes for renewable energy niches in South Africa; compiled from $[81,82,87]$

However, investment in renewable energy remained at a very low level because the tariff offered by the REFIT scheme was too high and not competitive with electricity produced from coal [88]. As a result, Eskom and other commercial consumers were not able to purchase renewable energy at a low enough price to offset the consumers' investment. María and Mucci [89] say that although some investors were interested in the REFIT scheme, they were discouraged by the lack of any precise administrative mechanism for receiving the concessionary subsidy. 
In 2010 the government introduced the Integrated Resource Plan (IRP), the aim of which was to map a gradual transition toward a more sustainable and economically efficient energy policy. As part of the Plan, a target was set of $17.8 \mathrm{GW}$ of electricity capacity to be produced from renewables by 2030, of which $1.2 \mathrm{GW}$ was to become from CSP [90]. Specifically including CSP in the IRP target in this way certainly helped to raise expectations in the tiny niche that it occupied in the energy market. However, once again, the encouragement consisted of words unsupported by clear policies or resources.

It was not until the following year that aspiration was turned into practical action. The ineffective REFIT scheme was replaced by the Renewable Energy Independent Power Producer Programme (REIPPP), a public procurement facilitator aimed at enabling independent power producers (IPPs) to participate in competitive bids to design, develop and operate large-scale renewable energy plants [91]. The REIPPP provided a platform for IPPs to enter into power purchase agreements with Eskom [85]. Analysis of published reports indicates that the REIPPP successfully stimulated foreign investment in CSP, leading directly to the development of the seven CSP projects listed in Table 2.

The Bokpoort plant, for example, was constructed in 2013 near Groblershoop in the North Cape Province [16] with an innovative financing structure: $40 \%$ of its capital investment was raised domestically with a debt-to-equity ratio of $71 \%$ to $29 \%$ [92]. The debt financing of the project was provided by various international banks, including Investec, ABSA Bank Limited and Old Mutual Specialised, which together contributed US\$193 million [93]. Several national and international companies also invested in the project. The CSP technologies were imported from Spain and most of the technical development was carried out by international companies that had won the REIPPP bids. 
Regrettably, despite the international acclaim which the Bokpoort plant and other CSP plants had received, in August 2018 the South African government published a revised version of IRP 2010. This significantly changed the target capacity allocated to renewable energy and excluded CSP development from the REIPPP [94]. Understandably, this caused considerable dismay within the CSP industry and expectations were disappointed even further when Eskom recently announced it was withdrawing from a CSP project to pursue solar PV [94]. At present, no further CSP projects are planned [16]. However, the main barrier to the further development of CSP projects in South Africa remains the high capital cost of these projects. Currently, the cost of energy from CSP plants in South Africa is still much higher than the cost of energy from conventional (such as coal) and renewable sources [91]. The cost of energy generated by CSP plants in South Africa is five times higher than that generated from coal [91].

\subsubsection{Role of social network in the development of CSP industry in South}

\section{Africa}

The social network associated with the CSP niche in South Africa did not begin to function until 2011. It was comprised almost entirely of the Spanish companies responsible for the small number of projects that had begun to be developed with the introduction of the REIPPP scheme [95]. Initially, due to unfamiliarity with CSP technology, it was difficult to recruit local actors into the network. This reflected the general conservatism of the entrepreneurial culture in South Africa: local financial institutions and companies were reluctant to support innovative technologies with no record of domestic success [95]. This was why the debt financing of the Bokpoort project had to be provided almost entirely by various international banks [93].

The successful development of projects like Bokpoort attracted worldwide interest and the social network of CSP interest in South Africa undoubtedly grew as a result. In 2015, the country hosted the SolarPace conference, a prestigious gathering of academics and 
industrialists who were all committed to CSP technologies [96]. This provided an opportunity for interaction between a wide range of actors, including local companies, government organisations and global leaders in the CSP sector.

Our analysis indicates the social network promoting the diffusion of CSP technologies in the country currently faces several discouragements, including a lack of interest by local companies, high transportation costs for importing the materials required by CSP projects, and the inability of local labour to match the productivity of labour provided by international companies [95].

\subsubsection{Role of learning in the diffusion of CSP in South Africa}

The CSP projects in South Africa depended very heavily on international companies that had constructed operational CSP projects elsewhere, especially in Spain. If CSP was to take root in South African soil, knowledge and experience needed to be shared with local actors. However, the evidence is that the diffusion of such learning has been minimal. Among the obstacles that have been identified are lack of funds, which hinders local research and development, so there is little potential for CSP project designers to communicate their vision, and lack of skilled local labour, which hinders both the construction and the operation of CSP projects, and it is unclear how this skills gap can be filled [10, 93, 97].

\subsection{Discussion}

Our research indicates that the CSP industry in California was successfully established mainly because of government support schemes. One of the main success factors of CSP niche development in the US was the strategic and consistent funding scheme. The US funding schemes provided both capital funding (loan guarantee) and revenue payment (Sunshot initiatives) to cover financial risk and build trust for private investors (Table 3). This provided 
a significant opportunity for CSP niches at the early stage of their development, enabling them to emerge in the US market successfully.

In contrast to the US, the South African support scheme only provides revenue payment. The REIPPP, which is the main CSP support scheme in South Africa, only provides a platform for CSP projects to participate in power purchase agreements that sell their electricity to the Eskom utility. Although this has reduced the commercial risk associated with CSP projects to some extent and attracted some international investment, it has not been sufficient to convince local financial institutions and companies to get involved. Local South African companies are also unable to compete with international companies in productivity and labour costs. Furthermore, the recent exclusion of CSP projects from the REIPPP has put the future development of CSP in South Africa in doubt. To reduce the financial risk of CSP projects, the South Africa government should restore them to the REIPPP once again.

Eskom in 2019 announced it was withdrawing from a CSP project to pursue solar PV. In addition to the lack of consistent strategic policy support, the high capital costs of CSP projects and Eskom's financial constraints have also played a role in the slow uptake of CSP projects in South Africa [94].

South Africa has fewer highly educated people than is the case in other parts of the world. The highest level of education achieved by $60 \%$ of 25 to 64 year olds in South Africa is an upper secondary diploma $[82,97]$. Under-qualified labour is likely to understand neither the expertise that the Spanish staff crucially brought to the project nor the usefulness of renewable energy [89]. This has undoubtedly obstructed the rate of development and the diffusion of CSP technologies. 
Table 3: Strengths and weaknesses of CSP development in the US and South Africa using SNM framework

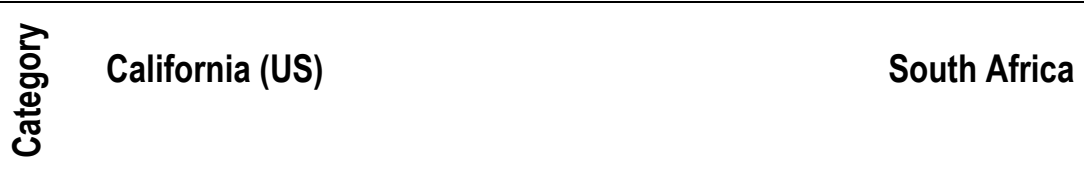

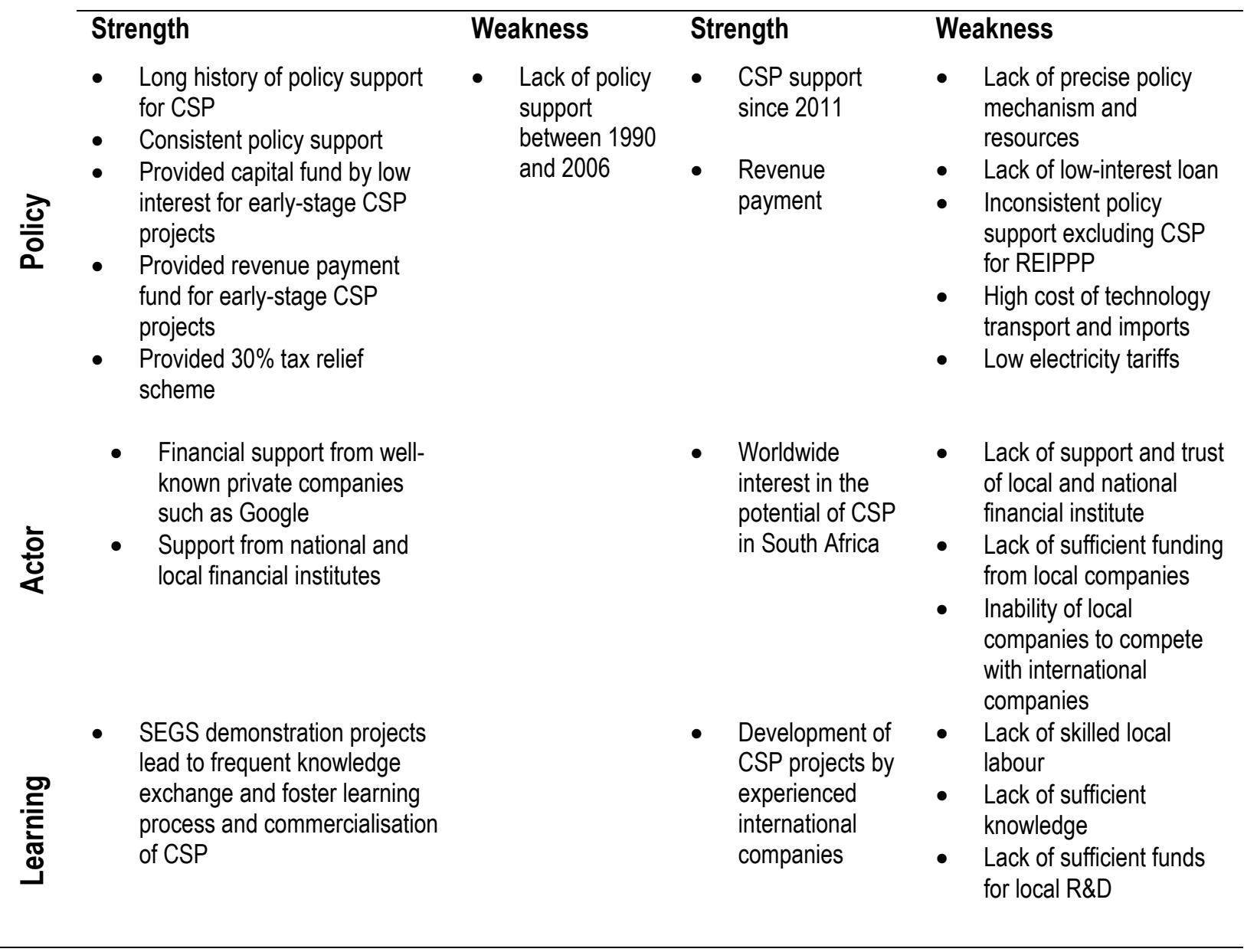

This study findings support the observations of Opazo [20] and Trieb et al. [9] that a lack of technological expertise is among several problems that hinder the development of innovative technologies such as CSP in developing countries. To solve this problem, strategic support, in the form of, for example, technical skills training, should be provided by CSP developers to facilitate interaction between local labour and international staff.

South Africa is facing a severe developmental crisis because coal plays such an essential role in its economy. But large-scale adoption of CSP is a formidably daunting prospect. The transformation of the South African energy system is an example of 'limited path dependency' 
with a strong tendency in the status quo. Which means, the process of implementing more renewable energy is inevitably going to be conditioned by the country's historical pattern of energy generation. Considering the vertical integration of South Africa's energy system, another challenge facing CSP development and the transformation of South Africa's energy system is the powerful governing interest in maintaining the regime [98]. As a consequence, significant political and economic change is required in South Africa, if it is not to remain 'locked into' existing technologies indefinitely [99].

\section{Conclusion}

This paper reviewed and compared diffusion and uptake of CSP technologies in the US and South Africa, with a focus on the internal niche process. Our study found that the main reason for the successful diffusion and adoption of CSP in California has been consistent policy support, including the $30 \%$ investment tax credit, the loan guarantees and the SunShot initiative. These policies have shaped the positive expectations for CSP projects and provided opportunities for CSP niches to emerge in the market. By contrast, despite some recent growth of CSP projects in South Africa, the development of CSP in this country has been held back by the lack of consistent policy support and by financial obstacles such as high capital costs and a lack of funding. The collapse in expectations when the exclusion of CSP projects from the REIPPP was announced caused considerable dismay in the CSP industry.

Our analysis indicates that support from social network and private companies played a critical role in niche stability and successful diffusion of CSP in California. South Africa has struggled to recruit local actors into the network and engage local companies for CSP projects. South African companies are perhaps more risk-averse than those in California. 
The sequential development of SEGS projects between 1984 and 1990 led to frequent knowledge exchange and this played an essential role in techno-economic learning in the CSP industry in the US as well as worldwide. The CSP plants that have been built in South Africa have depended very heavily on international companies, in particular Spanish companies and we found that there has been very little sharing of knowledge and experience with local actors.

In summary, Opazo [20] and Trieb et al.[9] are surely right to observe that the establishment of innovative technologies, such as CSP, in developing countries, presents problems specific to those countries that need to be sympathetically acknowledged. Not all the experience of the CSP industry in the US is directly transferable to South Africa. However, some lessons can be learnt. One measure most likely to accelerate the uptake of CSP projects in South Africa would be the introduction of a capital funding scheme the US loan guarantee programme. This would provide an opportunity for CSP niches to emerge successfully in the market by reducing the commercial risk associated with CSP projects and engaging more local actors in these projects.

The paper discussed the vital role of policy incentives, social networks and knowledge exchange in niche formation. The role of local public companies, to some extent, did not overcome ongoing challenges of development. In this regard, we feel that the impact of the geopolitical situation and the objective of funding provided by international funding agencies need more research, to enhance the understanding of the effect of the role of actors in the diffusion of renewable technology in developing countries. 


\section{References}

[1] IEA, Technology Roadmap Solar Thermal Electricity, 2014.

[2] Center for Global Development, Developing Countries Are Responsible for 63 Percent of Current Carbon Emissions, (2015) 1-2. https://www.cgdev.org/media/developingcountries-are-responsible-63-percent-current-carbon-emissions (accessed September $30,2019)$.

[3] G.C. Aye, P.E. Edoja, Effect of economic growth on $\mathrm{CO} 2$ emission in developing countries: Evidence from a dynamic panel threshold model, Cogent Econ. Financ. 5 (2017) 1-22. https://doi.org/10.1080/23322039.2017.1379239.

[4] A. Pegels, Renewable energy in South Africa: Potentials, barriers and options for support, Energy Policy. 38 (2010) 4945-4954. https://doi.org/10.1016/j.enpol.2010.03.077.

[5] F.V. Bekun, F. Emir, Samuel Asumadu Sarkodie, Another look at the relationship between energy consumption, carbondioxide emissions, and economic growth in South Africa, Sci. Total Environ. 655 (2019) 1-19.

[6] Carbon Brief, South Africa, Carbon Breif. (2018) 1-23. https://www.carbonbrief.org/the-carbon-brief-profile-south-africa (accessed September $30,2019)$.

[7] E. van der Westhuizen, J. Young, Perceived success of energy strategies for South Africa's financial services industry, J. Energy South. Africa. 29 (2018) 66-74. https://doi.org/10.17159/2413-3051/2018/v29i3a5273. 
[8] M. Chaanaoui, S. Vaudreuil, T. Bounahmidi, Benchmark of Concentrating Solar Power Plants: Historical, Current and Future Technical and Economic Development, in: Procedia Comput. Sci., Elsevier Masson SAS, 2016: pp. 782-789. https://doi.org/10.1016/j.procs.2016.04.167.

[9] F. Trieb, T. Fichter, M. Moser, Concentrating solar power in a sustainable future electricity mix - Engineering Research Database - ProQuest, (2014) 1-6. https://doi.org/https://doi.org/10.1007/s11625-013-0229-1.

[10] P. del Río, C.P. Kiefer, Analysis of the Drivers and Barriers to the Market Uptake of CSP in the EU., 2018. https://www.solarpaces.org/wpcontent/uploads/Analysis_of_the_drivers_and_barriers.pdf.

[11] H. Wenzlawski, R. Tol, The global CSP market - its industry, structure and decision mechanisms, Fachbereich Wirtschaftswiss. (2003) 85.

[12] K. Mohammadi, H. Khorasanizadeh, The potential and deployment viability of concentrated solar power (CSP) in Iran, Energy Strateg. Rev. 24 (2019) 358-369. https://doi.org/10.1016/j.esr.2019.04.008.

[13] P. del Río, C. Peñasco, P. Mir-Artigues, An overview of drivers and barriers to concentrated solar power in the European Union, Renew. Sustain. Energy Rev. 81 (2018) 1019-1029. https://doi.org/10.1016/j.rser.2017.06.038.

[14] SOLSRGIS, Solar resource maps and GIS data for 180+ countries | Solargis, Solargis. (2019) All.

[15] P. Gauché, T.W. Von Backström, A.C. Brent, A concentrating solar power value proposition for South Africa, J. Energy South. Africa. 24 (2013) 66-76. 
https://doi.org/10.17159/2413-3051/2013/v24i1a3122.

[16] National Renewable Energy Laboratory, Concentrating Solar Power Projects, Natl. Renew. Energy Lab. (2019) 1-2. https://solarpaces.nrel.gov/.

[17] M. Labordena, A. Patt, M. Bazilian, M. Howells, J. Lilliestam, Impact of political and economical barriers for concentrating solar power in Sub-Saharan Africa, Energy Policy. 102 (2017) 52-72. https://doi.org/10.1016/j.enpol.2016.12.008.

[18] T. Schinko, N. Komendantova, De-risking investment into concentrated solar power in North Africa: Impacts on the costs of electricity generation, Renew. Energy. 92 (2016) 262-272. https://doi.org/10.1016/j.renene.2016.02.009.

[19] R. Mahia, R. De Arce, E. Medina, Assessing the future of a CSP industry in Morocco, Energy Policy. 69 (2014) 586-597. https://doi.org/10.1016/j.enpol.2014.02.024.

[20] Jose Opazo, The politics of system innovation for emerging technologies : Understanding the uptake of off-grid, (2014). http://sro.sussex.ac.uk/54509/.

[21] H. Elmustapha, T. Hoppe, H. Bressers, Comparing two pathways of strategic niche management in a developing economy; the cases of solar photovoltaic and solar thermal energy market development in Lebanon, J. Clean. Prod. 186 (2018) 155-167. https://doi.org/10.1016/j.jclepro.2018.03.098.

[22] R. Kemp, J. Schot, R. Hoogma, Technology Analysis \& Strategic Management Regime shifts to sustainability through processes of niche formation : The approach of strategic niche management, 7325 (1998). https://doi.org/10.1080/09537329808524310.

[23] A. Al, S. Judith, Assessing strengths and weaknesses of renewable energy initiatives in 
Oman : an analysis with strategic niche management, Energy Transitions. 2 (2018) 1529. https://doi.org/10.1007/s41825-018-0008-9.

[24] E. González-roubaud, D. Pérez-osorio, C. Prieto, Review of commercial thermal energy storage in concentrated solar power plants : Steam vs . molten salts, Renew. Sustain. Energy Rev. 80 (2017) 133-148. https://doi.org/10.1016/j.rser.2017.05.084.

[25] D. Aidroos, H. Abdul, W. Zaidi, W. Omar, Historical development of concentrating solar power technologies to generate clean electricity ef fi ciently - A review, Renew. Sustain. Energy Rev. 41 (2015) 996-1027. https://doi.org/10.1016/j.rser.2014.09.008.

[26] T. Mancini, P. Heller, B. Butler, B. Osborn, W. Schiel, V. Goldberg, R. Buck, C. Andraka, J. Moreno, Dish-Stirling Systems : An Overview of Development Richard Diver $\dagger, 125$ (2019). https://doi.org/10.1115/1.1562634.

[27] J. Gretz, Solar Thermal Electricity Generation EURELIOS , the $1 \mathrm{MW}$ ( el ) Helioelectric Power Plant of the European Communities, (2007) 3-5.

[28] REN21, Renewables 2019 Global Status Report, 2019. https://www.ren21.net/wpcontent/uploads/2019/05/gsr_2019_full_report_en.pdf.

[29] Business Wire, Global Concentrated Solar Power (CSP) Market Size, Segmentation, Competitive Landscape and Key Country Analysis (2010-2030) - Research And Markets, 2019. https://www.businesswire.com/news/home/20190520005654/en/Global-ConcentratedSolar-Power-CSP-Market-Size.

[30] World Energy Council, Energy resources > wind, (2019) 1-2. https://www.worldenergy.org/data/resources/resource/wind/. 
[31] K. Kaygusuz, Prospect of concentrating solar power in Turkey: The sustainable future, Renew. Sustain. Energy Rev. 15 (2011) 808-814.

https://doi.org/10.1016/j.rser.2010.09.042.

[32] J. Khan, M.H. Arsalan, Solar power technologies for sustainable electricity generation - A review, Renew. Sustain. Energy Rev. 55 (2016) 414-425. https://doi.org/10.1016/j.rser.2015.10.135.

[33] R. Varpe, CONCENTRATED SOLAR POWER INDUSTRY BY GROWTH , TREND AND FORECAST 2024, (2019) 1-4. http://technologymagazine.org/concentrated-solar-power-market-industry-growthtrend-forecast-2024/.

[34] International Renewable Energy Agency, Renewable Power Generation Costs in 2017, 2018. https://doi.org/10.1007/SpringerReference_7300.

[35] K. Bataineh, A. Algharaibeh, Optimization Analyses of Parabolic Trough ( CSP ) Plants for the Desert Regions of the Middle East and North Africa ( MENA ), (2018).

[36] M.G. Ali Sulaiman Alsagri, Andrew Chiasson, Viability Assessment of a Concentrated Solar Power Tower With a Supercritical CO 2 Brayton Cycle Power Plant, 141 (2019) 1-15. https://doi.org/10.1115/1.4043515.

[37] J. Lilliestam, J.M. Bielicki, A.G. Patt, Comparing carbon capture and storage (CCS) with concentrating solar power (CSP): Potentials, costs, risks, and barriers, Energy Policy. 47 (2012) 447-455. https://doi.org/10.1016/j.enpol.2012.05.020.

[38] J. Rogers, L. Wisland, Solar Power on the Rise, (2014) 1-16.

[39] G. Frisari, J. Feás, The role of public finance in CSP, (2014). 
https://climatepolicyinitiative.org/wp-content/uploads/2014/08/SGG-Brief---TheRole-of-Public-Finance-in-CSP-How-Spain-created-a-world-leading-industry-thenshattered-investor-confidence.pdf.

[40] J. Rudman, P. Gauché, K.J. Esler, Initial review and analysis of the direct environmental impacts of CSP in the northern Cape, South Africa, AIP Conf. Proc. 1734 (2016). https://doi.org/10.1063/1.4949256.

[41] G.A. Otieno, A.E. Loosen, An analysis of key environmental and social risks in the development of concentrated solar power projects, AIP Conf. Proc. 1734 (2016). https://doi.org/10.1063/1.4949253.

[42] J. Terrapon-Pfaff, T. Fink, P. Viebahn, E.M. Jamea, Determining significance in social impact assessments (SIA) by applying both technical and participatory approaches: Methodology development and application in a case study of the concentrated solar power plant NOORO I in Morocco, Environ. Impact Assess. Rev. 66 (2017) 138-150. https://doi.org/10.1016/j.eiar.2017.06.008.

[43] J. Terrapon-Pfaff, Social CSP: Energy and development: exploring the local livelihood dimension of the NOORo I CSP project in Southern Morocco, (2015). https://epub.wupperinst.org/frontdoor/deliver/index/docId/6444/file/6444_Social_CSP. pdf.

[44] 5 Capitals, Noor III Tower CSP Plant, Ouarzazate, Morocco-Specific Environmental and Social Impact Assessment, Study Prep. By. 5 (2015).

[45] S. Hanger, N. Komendantova, B. Schinke, D. Zejli, A. Ihlal, A. Patt, Community acceptance of large-scale solar energy installations in developing countries: Evidence from Morocco, Energy Res. Soc. Sci. 14 (2016) 80-89. 
https://doi.org/10.1016/j.erss.2016.01.010.

[46] IRENA, Technology Brief E10-Concentrating Solar Power ENERGY TECHNOLOGY SYSTEMS ANALYSIS PROGRAMME, (2013). www.etsap.orgwww.irena.org.

[47] L.J. Walston Jr., K.E. Rollins, K.P. Smith, K.E. LaGory, A Review of Avian Monitoring and Mitigation Information at Existing Utility- Scale Solar Facilities, (2015) 82.

[48] EnvironQuest, Final Environmental and Social Impact Assessment Report for the Proposed 100MW Solar Independent Power Plant and 18 KM Transmission Line Project, Ganjuwa Local Government Area , Bauchi State by Nigerian Solar Capital Partners / Globeleq / ARM- Harith Jun, 2017.

[49] T. Conroy, M.N. Collins, J. Fisher, R. Grimes, Thermohydraulic analysis of single phase heat transfer fl uids in CSP solar receivers, Renew. Energy. 129 (2018) 150167. https://doi.org/10.1016/j.renene.2018.05.101.

[50] J.C.C.M. Huijben, G.P.J. Verbong, Breakthrough without subsidies? PV business model experiments in the Netherlands, Energy Policy. 56 (2013) 362-370. https://doi.org/10.1016/j.enpol.2012.12.073.

[51] F.W. Geels, The multi-level perspective on sustainability transitions: Responses to seven criticisms, Environ. Innov. Soc. Transitions. 1 (2011) 24-40. https://doi.org/10.1016/j.eist.2011.02.002.

[52] D. Loorbach, Strategic Niche Management and Transition Management: different but complementary approaches, 2006. 
[53] J. Schot, F.W. Geels, Strategic niche management and sustainable innovation journeys: theory, findings, research agenda, and policy, Technol. Anal. Strateg. Manag. 20 (2008) 537-554. https://doi.org/10.1080/09537320802292651.

[54] M.C.J. Caniëls, H.A. Romijn, Strategic niche management: Towards a policy tool for sustainable development, Technol. Anal. Strateg. Manag. 20 (2008) 245-266. https://doi.org/10.1080/09537320701711264.

[55] G. Seyfang, S. Hielscher, T. Hargreaves, M. Martiskainen, A. Smith, A grassroots sustainable energy niche? Reflections on community energy in the UK, Environ. Innov. Soc. Transitions. 13 (2014) 21-44. https://doi.org/10.1016/j.eist.2014.04.004.

[56] R.K. Arie Rip, R.P.M. Kemp, Technological Change, in: Faculty of Behavioural, Management and Social Sciences, 1998. https://research.utwente.nl/en/publications/technological-change.

[57] M. Borup, N. Brown, K. Konrad, H. Van Lente, The sociology of expectations in science and technology, Technol. Anal. Strateg. Manag. 18 (2006) 285-298. https://doi.org/10.1080/09537320600777002.

[58] S. Bakker, H. Van Lente, M. Meeus, Arenas of expectations for hydrogen technologies, Technol. Forecast. Soc. Change. 78 (2011) 152-162. https://doi.org/10.1016/j.techfore.2010.09.001.

[59] K. Konrad, The social dynamics of expectations: The interaction of collective and actor-specific expectations on electronic commerce and interactive television, Technol. Anal. Strateg. Manag. 18 (2006) 429-444. https://doi.org/10.1080/09537320600777192. 
[60] M. Martiskainen, Developing Community Energy Projects : experiences from Finland and the UK, University of Sussex, 2014. http://sro.sussex.ac.uk/51506/.

[61] Y. Xue, J. You, X. Liang, H.C. Liu, Adopting strategic niche management to evaluate EV demonstration projects in China, Sustain. 8 (2016).

https://doi.org/10.3390/su8020142.

[62] F.W. Geels, Ontologies, socio-technical transitions (to sustainability), and the multilevel perspective, Res. Policy. 39 (2010) 495-510.

https://doi.org/10.1016/j.respol.2010.01.022.

[63] R. Raven, S. Van den Bosch, R. Weterings, Transitions and strategic niche management: towards a competence kit for practitioners, Int. J. Technol. Manag. 51 (2010) 57. https://doi.org/10.1504/ijtm.2010.033128.

[64] W.W.M. van der Laak, R.P.J.M. Raven, G.P.J. Verbong, Strategic niche management for biofuels: Analysing past experiments for developing new biofuel policies, Energy Policy. 35 (2007) 3213-3225. https://doi.org/10.1016/j.enpol.2006.11.009.

[65] F.W. Geels, J.J. Deuten, Local and global dynamics in technological development: a socio-cognitive perspective on knowledge flows and lessons from reinforced concrete, Sci. Public Policy. 33 (2006) 265-275.

[66] A. Sharma, A comprehensive study of solar power in India and World, Renew. Sustain. Energy Rev. 15 (2011) 1767-1776. https://doi.org/10.1016/j.rser.2010.12.017.

[67] Federal Energy Regulatory Commission, FERC : Electric Power Markets - National Overview, 2019. https://www.ferc.gov/market-oversight/mkt-electric/overview.asp.

[68] US Environmental Protection Agency, U . S . Electricity Grid \& Markets, 2018. 
https://www.epa.gov/greenpower/us-electricity-grid-markets.

[69] T. Islam, N. Huda, R. Saidur, Current energy mix and techno-economic analysis of concentrating solar power ( CSP ) technologies in Malaysia, Renew. Energy. 140 (2019) 789-806. https://doi.org/10.1016/j.renene.2019.03.107.

[70] I.S. Radonji, D.D. Milosavljevi, L.S. Panti, A review of concentrating solar power plants in the world and their potential use in Serbia, 16 (2012) 3891-3902. https://doi.org/10.1016/j.rser.2012.03.042.

[71] National Renewable Energy Laboratory, National Solar Radiation Database, 2017. https://nsrdb.nrel.gov/api-instructions.

[72] U.S. Department of Energy, 2014: The Year of Concentrating Solar Power, (2014) 13.

[73] Helioscsp.com, Concentrated Solar Power experience in the USA, (2019) 1-6. helioscsp.com/concentrated-solar-power-experience-in-the-usa/\%0D.

[74] US Department of Energy, Concentrating Solar Power, (2011). https://www.nrel.gov/docs/fy12osti/52478.pdf.

[75] National Public Radio, California Sets Goal Of 100 Percent Clean Electric Power By 2045, (2018) 1-11. https://www.npr.org/2018/09/10/646373423/california-sets-goalof-100-percent-renewable-electric-power-by-2045?t=1565011527767.

[76] M. Mehos, C. Turchi, J. Jorgenson, P. Denholm, C. Ho, K. Armijo, On the path of SunShot: Advancing Concentrating Solar Power Technology, Performance, and Dispatchability, SunShot. (2016) 1-66. https://doi.org/10.1016/B978-0-08-087872$0.00319-X$. 
[77] IEA, South Africa Energy Outlook Analysis from Africa Energy Outlook 2016, (2016) 1-10. https://www.iea.org/articles/south-africa-energy-outlook.

[78] D. Modise, V. Mahotas, Overview of the South African energy sector sources of power, (2014).

[79] S.E. Trabelsi, L. Qoaider, A. Guizani, Investigation of using molten salt as heat transfer fluid for dry cooled solar parabolic trough power plants under desert conditions, Energy Convers. Manag. 156 (2018) 253-263. https://doi.org/10.1016/j.enconman.2017.10.101.

[80] Solargis, solar resource maps and GIS data Solar resource maps of South Africa, (2019) 1-5. https://solargis.com/maps-and-gis-data/download/south-africa.

[81] H. Winkler, Renewable energy policy in South Africa: Policy options for renewable electricity, Energy Policy. 33 (2005) 27-38. https://doi.org/10.1016/S03014215(03)00195-2.

[82] A. Nakumuryango, R. Inglesi-Lotz, South Africa's performance on renewable energy and its relative position against the OECD countries and the rest of Africa, Renew. Sustain. Energy Rev. 56 (2016) 999-1007. https://doi.org/10.1016/j.rser.2015.12.013.

[83] Department of Energy, Independent Power Producers Procurement Programme, 2003. https://doi.org/http://dx.doi.org/9771682584003-32963.

[84] Department of Science and Technology, SOUTH AFRICA' S CLIMATE CHANGE TECHNOLOGY NEEDS, 2007. file://C:/Users/e805890/Desktop/Resource Document for South Africa's Climate Change Technology Needs'.pdf.

[85] P. Papapetrou, Enabling Renewable Energy in South Africa : Assessing the Renewable 
Energy Independent Power Producer, 2014.

http://awsassets.wwf.org.za/downloads/enabling_re_in_sa.pdf.

[86] IEA, Renewable Energy Feed-in Tari ( REFIT ), (2011) 1-4.

https://www.iea.org/policiesandmeasures/pams/southafrica/name-24547-en.php.

[87] Department of Energy, Integrated Resource Plan, 2011.

http://www.energy.gov.za/IRP/2010/IRP_2010.pdf.

[88] K. Grant, Concentrated solar power in South Africa, Clim. Policy. 9 (2009) 544-552. https://doi.org/10.3763/cpol.2009.0637.

[89] J. María, H. Mucci, Khi Solar One Project Overview and Economic Analysis by, (2015).

[90] Department of Energy, Electricity Regulation on the Integrated Resource Plan 2010 2030, 2011. http://www.energy.gov.za/IRP/2010/IRP_2010.pdf.

[91] I.J. Pieters, M. Lotz, A.C. Brent, Investigating the financial close of projects within the South African renewable energy independent power producer procurement programme, South African J. Ind. Eng. 25 (2014) 57-68. https://doi.org/10.7166/25-3912.

[92] M. Rycroft, Power from the sun: An overview of CSP in South Africa, Ee Publ. (2018) 1. http://www.ee.co.za/article/power-from-the-sun-an-overview-of-csp-in-southafrica.html.

[93] J. Harnmeijer, G. Ibikunle, The Potential Role of CSP in South Africa, 2015. https://static1.squarespace.com/static/536b92d8e4b0750dff7e241c/t/55f2af0ae4b0dbda 5ff1d68f/1441967882201/Jane+Martin+(2015)+The+Potential+Role+of+CSP+in+Sou 
th+Africa.pdf.

[94] J. Larmuth, A. Cuellar, An updated review of South African CSP projects under the renewable energy independent power producer procurement programme (REIPPPP), SOLARPACES 2018 Int. Conf. Conc. Sol. Power Chem. Energy Syst. 2126 (2019) 040001. https://doi.org/10.1063/1.5117581.

[95] O.O. Craig, A. Brent, F. Dinter, the Current and Future Energy Economics of Concentrating Solar Power (Csp) in South Africa, South African J. Ind. Eng. 28 (2017). https://doi.org/10.7166/28-3-1835.

[96] Solarpaces, Cape Town, South Africa Overview Data SolarPACES 2015, (2015) 1316. https://www.solarpaces.org/all-solarpaces-conferences/21st-solarpaces-conference13-16-october-2015-capetown-southafrica/.

[97] OECD.org, South Africa Education at a Glance 2019, J. Commonw. Lit. 54 (2019) 677-699. https://doi.org/10.1177/0021989419877069.

[98] M.B. Ting, R. Byrne, Eskom and the rise of renewables: Regime-resistance, crisis and the strategy of incumbency in South Africa's electricity system, Energy Res. Soc. Sci. 60 (2020) 101333. https://doi.org/10.1016/j.erss.2019.101333.

[99] M. Winskel, N. Markusson, B. Moran, H. Jeffrey, G. Anandarajah, N. Hughes, C. Candelise, D. Clarke, G. Taylor, H. Chalmers, G. Dutton, P. Howarth, S. Jablonski, C. Kalyvas, D. Ward, Decarbonising the UK Energy System: Accelerated Development of Low Carbon Energy Supply Technologies, 2009. http://www.ukerc.ac.uk/Downloads/PDF/U/UKERCEnergy2050/TAcceleration\%7B_ \%7DDraft.pdf. 
